\title{
Strawberry Growth and Productivity in Fumigated Compared to Compost-amended Production Systems
}

\author{
Leonor F.S. Leandro, Lisa M. Ferguson, and Frank J. Louws \\ Department of Plant Pathology, Box 7616, North Carolina State University, \\ Raleigh, NC 27695
}

\section{Gina E. Fernandez ${ }^{1}$ \\ Department of Horticultural Science, Box 7609, North Carolina State University, Raleigh, NC 27695}

Additional index words. Fragaria $\times$ ananassa, plug transplants, biocontrol, choloropicrin, plasticulture, fumigation alternatives, Trichoderma

\begin{abstract}
Strawberry (Fragaria $\times$ ananassa Duchnesne) growth and productivity were compared in fumigated and nonfumigated production systems. Strawberry transplants grown in potting mix amended with Trichoderma hamatum (Bonord.) Bainier, strain T382, Trichoderma harzianum Rifai, strain T22, or untreated, were planted in field plots treated with compost, compost amended with $T$. hamatum strain T382, Telone-C35, or not treated. Plants were sampled throughout the growing season, and dry weights of roots, crowns, leaves, flowers and fruit, leaf area, and total and marketable yield were determined. Trichoderma amendments to the potting mix improved plant dry weight and leaf area of strawberry transplants in the first year and suppressed root rot incidence in the second year but did not affect plant growth or disease incidence once the plants were set in the field. Field plants in fumigated plots had greater root, leaf, and crown dry weights, leaf area, and yield compared with plants in the other soil treatments. We conclude that Trichoderma amendments (1) alone had little benefit to plug plant growth and (2) in combination with compost, had no benefit to strawberry plant growth in the field. The task remains to develop a reliable and sustainable strawberry production system that does not rely on chemical fumigants.
\end{abstract}

Strawberry production is an important source of income for growers in the southeastern region of the United States. Gross returns can range from $\$ 21,000$ to just over $\$ 30,000$ per acre with an estimated $\$ 13,556$ in total harvest and production costs per acre (Sydorovych et al., 2006). Most strawberry enterprises in this region comprise small to mid-sized family farms with an average size of 3-5 acres (Safley et al., 2004). These farms can be managed more intensely and are more likely to use alternative farming systems compared with large-acreage operations.

Growers are currently faced with the serious challenge of implementing alternatives to soil fumigation with methyl bromide (Wilhelm and Paulus, 1980; Yuen et al., 1991), banned in 2005 due to its ozone-

Received for publication 6 June 2006. Accepted for publication 11 Oct. 2006.

This research was partially funded by USDA Grant 2002-51102-01926.

We gratefully acknowledge Marcia Gumpertz, NCSU Statistics Department, for support with the statistical analysis. We also thank Mark Clough, Nastacia Heiniger, Jim Driver, Amanda Capps, Mike Carnes, and Joey Nemargut for technical assistance.

${ }^{1}$ To whom correspondence and reprint requests should be addressed; e-mail Gina_Fernandez@ ncsu.edu. depleting characteristics (EPA, 1999). Alternative fumigants, such as chloropicrin, metam sodium, 1,3-dichloropropene, and combinations of these (Martin, 2003), are now available with varying levels of performance. However, many growers, including those who desire to implement organic systems, have expressed interest in management systems that are not dependent on chemical soil fumigation but rely on biologically based approaches, such as the use of cover crops and compost.

Organic amendments, such as compost, are widely available and offer the advantage of improving soil properties, adding nutrients, and recycling wastes (Millner et al., 2004). In addition, composts may enhance plant growth and suppress plant pathogens by naturally introducing beneficial microbial populations, or by amendment with commercial biocontrol strains (De Ceuster and Hoitink, 1999; Hoitink et al., 1997). The fungus Trichoderma, for example, is well known for its ability to stimulate plant growth and suppress root pathogens in greenhouse and field conditions (Harman, 2000; Howell, 2003), but few studies have tested these strains during strawberry production (Elad et al., 1981).

A primary limitation to yield in most strawberry production regions is the complex of pathogens that result in black root rot
(Maas, 1998; Wing and Pritts, 1994). In earlier trials, we observed that compost applications were as effective as methyl bromide in increasing yield above that observed in untreated soil (Grabowski, 2001; Louws et al., 2000), suggesting that compost could be a viable disease-management alternative to soil fumigation. We also characterized the spectrum of fungi associated with roots of strawberry transplants and identified the risk of pathogen introduction via these transplants into production fields (Abad et al., 2002; Ferguson et al., 2003). Use of infested propagation material causes problems for nursery growers and compromises the effectiveness of disease-management practices applied to field soil. There is a need to develop transplant production systems that reduce the risk of introducing root pathogens into fields and that ensure plant vigor and productivity.

Root dips with Trichoderma harzianum strain T22 (T22) and other biocontrol agents have suppressed root rot and enhanced growth of fresh-dug strawberry transplants (Olatinwo and Schilder, 2002). For plug production systems, addition of biocontrol agents to potting mix shows potential because the plug roots can develop in direct contact with the biocontrol agent. Trichoderma hamatum strain T382 (T382) is an effective biocontrol agent in potting systems for ornamental and vegetable crops (Chung and Hoitink, 1990; Krause et al., 2001), suppressing root pathogens similar to those that cause rots on strawberries. However, to our knowledge, this strain has not been tested on strawberries or in field systems. The evidence above suggests that Trichoderma strains T22 and T382 may offer advantages for strawberry plug production systems. It is also necessary to evaluate if these plug treatments offer long-term benefits to the strawberry after field establishment and if a combination of plug and soil management practices are more beneficial than either approach alone. T382 was selected as a compost inoculant for our field trials due to previous reports of its effective colonization of organic matter in potting mixes (Chung and Hoitink, 1990; Krause et al., 2001).

The objective of this study was to compare strawberry growth and productivity in fumigated and alternative biologically based production systems. This objective was addressed at two levels: (i) during transplant production, where Trichoderma biocontrol strains were used as potting mix amendments, and (ii) during field production, where treated transplants were grown in field soil treated with the fumigant Telone C35 (61\% 1,3-dichloropropene/35\% chloropicrin), compost, compost amended with Trichoderma, and nontreated soil. Telone C35 was used as a chemical fumigant because it was previously found to be a cost-effective alternative to methyl bromide (Sydorovych et al., 2006). Companion studies on the effects of these treatments on root rot severity and pathogen dynamics have been reported elsewhere (Leandro et al., 2005). 


\section{Materials and Methods}

Transplant production. Strawberry transplants were produced in greenhouse conditions in Sept. 2002 (Year 1) and 2003 (Year 2) in potting media amended or not amended with Trichoderma biocontrol strains T382 (Chung and Hoitink, 1990) and T22 (Harman, 2000). The biocontrol agents were applied to commercial potting mix (BM1; 75\% to $85 \%$ Canadian sphagnum peatmoss, $15 \%$ to $20 \%$ perlite, $5 \%$ to $10 \%$ vermiculite; Berger International, Quebec) on the day of planting. T22 (Rootshield, Bioworks, Geneva, N.Y.) was added to potting mix at labeled rate [final concentration of $6 \times 10^{4} \mathrm{cfu}$ per gram $(\mathrm{cfu} / \mathrm{g})$ dry potting mix]. For the T382 treatment, potting mix was amended with $5 \%$ compost $(\mathrm{v} / \mathrm{v})$ inoculated with a granular formulation of T382 (Sylvan Bioproducts, Cabot, Pa.) to establish an initial population of T832 of $2 \times 10^{5} \mathrm{cfu} / \mathrm{g}$ dry potting mix. Untreated potting mix was used as a control. In Year 2, a combination of T22 and T382, each applied at the same rates as when applied alone, was added as a fourth treatment.

Strawberry runner tips (cv. Chandler) were planted into 50-cell trays containing the treated potting mix and maintained in a greenhouse for 4 weeks to produce transplants. Water was supplied by overhead misting during the first 2 weeks after planting, then once daily for an additional 2 weeks, according to the North Carolina recommendations for strawberry plug transplant production (Poling, 2001). A randomized complete block design with four replications was used in Year 2, but trays were not randomized in Year 1. On the day of field planting, transplants were sampled to evaluate plant growth (dry weights, leaf area, and feeder root development), and the remaining transplants were used to establish field trials. Eight representative transplants were sampled per treatment in Year 1, and 16 plants (4 plants per replicate) were sampled per treatment in Year 2.

Field production. Field trials were established at the Vernon G. James Research Station and Extension Center at the Tidewater Research Station, in Plymouth, N.C. (USDA hardiness Zone $7 \mathrm{~b}$, lat. $35^{\circ} 87^{\prime} \mathrm{N}$, long. $\left.76^{\circ} 65^{\prime} \mathrm{E}\right)$. The soil was a Meggett fine sandy loam under continuous strawberry production since 1996. A cover crop of millet and cowpea was grown in the trial area during the summer and tilled into the soil in the first week of September each year. Fertilization $\left(\mathrm{N}\right.$ at $67 \mathrm{~kg} \cdot \mathrm{ha}^{-1}, \mathrm{P}$ at $45 \mathrm{~kg} \cdot \mathrm{ha}^{-1}$, and $\mathrm{K}$ at $67 \mathrm{~kg} \cdot \mathrm{ha}^{-1}$ ) was applied before planting in all plots. The experimental design was a splitplot with four replications, using field soil treatments as main plots and transplant treatments as subplots. Four soil treatments were applied 1 month before planting as follows: fumigation with Telone C35, $1.4 \mathrm{~m}^{3} \cdot \mathrm{ha}^{-1}$ (Dow Agrosciences, Indianapolis); compost (composted cotton gin waste, Nash Produce, Nashville, N.C.; $57 \mathrm{~m}^{3} \cdot \mathrm{ha}^{-1}$ ); compost + T382 (composted cotton gin trash amended with $\mathrm{T} 382 ; 57 \mathrm{~m}^{3} \cdot \mathrm{ha}^{-1}$ ), and not treated or amended soil (control). The fumigant was shank applied 20-25 cm deep using a fumigant applicator equipped with two shanks spaced $25 \mathrm{~cm}$ apart. The equipment could simultaneously apply fumigant, form the beds, apply the drip tape and plastic mulch cover. For the compost + T382 treatment, compost was inoculated with $\mathrm{T} 382$ at a rate of $2 \times 10^{5} \mathrm{cfu} / \mathrm{g}$ dry weight and incubated for 2 weeks while covered with a semipermeable tarp to allow colonization by the biocontrol agent. Compost treatments were spread on each plot and rotovated into the soil just before making beds and laying plastic. Composted cotton gin trash was chosen for these studies because it has been previously used in North Carolina to suppress diseases in horticultural crops (Bulluck and Ristaino, 2002). Plots and subplots were established in the same location in both years to allow evaluation of the cumulative effect of the soil treatments.

Transplants, produced in the greenhouse as described above, were planted in the field on 4 Oct. 2002 and 7 Oct. 2003. Transplants were planted in raised beds $(76 \mathrm{~cm}$ wide $\times$ $20 \mathrm{~cm}$ high), covered with black polyethylene plastic, with $1.5 \mathrm{~m}$ between the center of adjacent beds. Each raised bed contained two rows of plants, staggered $30 \mathrm{~cm}$ apart within each row. Each main plot consisted of a $7.6 \mathrm{~m}$ long area on each of two adjacent beds, each area divided into two $3.6-\mathrm{m}$ long subplots (total of four subplots per main plot). Main plots within a bed were separated by a $7.6-\mathrm{m}$ long area where no strawberries were planted. Each subplot contained 18 plants in Year 1 and 24 plants in Year 2. Fewer plants were used in Year 1 because of plant loss due to theft; plants were kept under secure conditions in the second year. Five plants per subplot were designated for destructive sampling throughout the season, while the remaining plants were used for fresh fruit harvest. Irrigation was supplied by a single drip tape placed in the center of the row, and weeds were removed by hand in December and March.

Sampling. Soil was sampled on the day of planting (4 weeks after soil treatment application) for chemical and nematode analysis, and at full bloom for nematode analysis only. Four subsamples, one from the center of each subplot within a main plot, were taken using a soil core with a diameter of $10 \mathrm{~cm}$, and pooled to obtain a representative sample for the main plot. Soil samples were submitted to the North Carolina Department of Agriculture and Consumer Services in Raleigh, N.C. (NCDA\&CS), where the population of plant parasitic nematodes, including the lesion nematode, Pratylenchus penetrans, and soil nutrient and organic matter content were determined.

Whole plants were destructively sampled five times during the field growing season: 17 Dec., 26 Feb., 1 Apr., 13 May, and 29 May in Year 1 (2002-2003), and 4 Dec., 29 Feb., 5 Apr., 12 May, and 24 May in Year 2 (20032004). The last three sample times corresponded to the key growth stages of full bloom, peak fruiting, and final harvest. At each sampling time, a single plant was dug from each subplot following a predetermined sampling pattern, to ensure that the target plant was adjacent to plants on all sides. A $30 \times$ $30 \mathrm{~cm}$ area was dug $30 \mathrm{~cm}$ deep around the assigned plant, the plant was removed, and soil particles attached to the roots were shaken off. Plants were placed in plastic bags, stored in a cooler, and brought back to the laboratory for plant part assessments and root rating.

Plant assessments. Roots were washed under running tap water over a mesh sieve. Plants were then divided into roots, crowns, leaves (including petioles), and fruiting structures (flowers and fruit). The number of crowns was counted, and dry weight of leaves, roots, crowns, and fruiting structures was measured. Feeder root development was rated (rating $1-10$, where $1=$ none and $10=$ abundant) for each plant. Leaf area of fresh leaves was determined with a LI-COR LI3200 leaf area meter (LI-COR, Lincoln, $\mathrm{Neb}$.). In addition, root rot severity, defined as the percentage of root area showing rot symptoms, was evaluated on transplants.

Ripe fruit was harvested twice per week and divided into marketable and nonmarketable berries. Berries that were deformed, weighed less than $15 \mathrm{~g}$, or showed lesions were considered nonmarketable. Marketable yield per plant, total yield per plant, and the average fruit weight were calculated.

Statistical analysis. A split-plot ANOVA was performed at each sampling time on all data using the general linear models (GLM) procedure of SAS (SAS Institute, Cary, N.C.). Statistical significance was expressed at the $P \leq 0.05$ level. Treatment means were separated according to Fisher's protected LSD test.

\section{Results}

Transplant production. Trichoderma applications to potting mix had a positive impact on plant dry weight and root rot severity of plug transplants but treatment effects were not consistent among repetitions of the trial. In Year 1, leaf area and root dry weight were greater $\left(98.7 \pm 26.3 \mathrm{~cm}^{2}\right.$ (SD) and $0.48 \pm 0.16 \mathrm{~g}(\mathrm{SD})$, respectively) for the T832 treatment than for the untreated control $\left(70.6 \pm 21.9 \mathrm{~cm}^{2}(\mathrm{SD})\right.$ and $0.29 \pm 0.14 \mathrm{~g}$ (SD)), but root rot severity and feeder root development was unaffected. In Year 2, root rot severity was significantly lower with values of $3 \%$ to $6 \%$ in all Trichoderma treatments compared with the untreated control $(10 \%)$, but there were no differences in plant dry weight or feeder root development.

Field trial. Soil treatments significantly affected plant dry weight (Table 1), feeder root development (Table 1), and yield (Table 2) in both years of the trial. There were no significant differences among plug treatments (data not shown), and there was no interaction between plug and soil treatments. In general, soil fumigation improved plant dry weight and feeder root development compared with all other soil treatments, 
Table 1. Dry weights of strawberry roots, crowns, leaves and fruiting structures (flowers + fruit), and feeder root rating, throughout the growing season in Year 1 (2002-2003) and Year 2 (2003-2004); strawberry plants (cv. Chandler) were grown in field soil with different soil treatments.

\begin{tabular}{|c|c|c|c|c|c|c|c|c|c|c|}
\hline \multirow[b]{2}{*}{ Treatment } & \multicolumn{5}{|c|}{ Year 1} & \multicolumn{5}{|c|}{ Year 2} \\
\hline & 13 Dec. & $26 \mathrm{Feb}$. & 1 Apr. & 13 May & 29 May & 3 Dec. & $19 \mathrm{Feb}$. & 5 Apr. & 12 May & 27 May \\
\hline Untreated & 2.08 & $2.45 \mathrm{ab}$ & $2.00 \mathrm{ab}$ & 1.38 & $3.52 \mathrm{~b}$ & $1.86 \mathrm{a}$ & 4.08 & 4.47 & 2.89 & $3.51 \mathrm{~b}$ \\
\hline Compost $+\mathrm{T} 382$ & 1.66 & $1.74 \mathrm{bc}$ & $1.61 \mathrm{bc}$ & 1.05 & $2.78 \mathrm{c}$ & $1.43 \mathrm{~b}$ & 4.24 & 3.92 & 2.79 & $3.03 \mathrm{c}$ \\
\hline Telone C35 & 1.80 & $2.88 \mathrm{a}$ & $2.34 \mathrm{a}$ & 1.81 & $4.61 \mathrm{a}$ & $1.60 \mathrm{~b}$ & 4.35 & 4.70 & 2.86 & $4.15 \mathrm{a}$ \\
\hline \multirow[t]{2}{*}{ LSD } & NS & 0.72 & 0.61 & NS & 0.66 & 0.24 & NS & NS & NS & 0.46 \\
\hline & \multicolumn{10}{|c|}{ Crowns (g) } \\
\hline Compost $+\mathrm{T} 382$ & - & 1.24 & $1.67 \mathrm{bc}$ & $2.89 \mathrm{~b}$ & $4.19 \mathrm{~b}$ & $0.68 \mathrm{~b}$ & $2.59 \mathrm{ab}$ & $3.29 \mathrm{~b}$ & $3.78 \mathrm{~b}$ & 3.58 \\
\hline Telone C35 & - & 1.40 & $3.16 \mathrm{a}$ & $4.71 \mathrm{a}$ & $7.22 \mathrm{a}$ & $0.85 \mathrm{a}$ & $3.25 \mathrm{a}$ & $5.23 \mathrm{a}$ & $5.03 \mathrm{a}$ & 5.42 \\
\hline \multirow[t]{2}{*}{ LSD } & - & NS & 0.64 & 1.08 & 1.99 & 0.12 & 0.71 & 1.23 & 0.87 & NS \\
\hline & \multicolumn{10}{|c|}{ Leaves $(\mathrm{g})$} \\
\hline Untreated & 2.03 & $2.84 \mathrm{~b}$ & $9.44 \mathrm{~b}$ & $26.88 \mathrm{~b}$ & $33.47 \mathrm{ab}$ & $5.66 \mathrm{ab}$ & 5.58 & $9.60 \mathrm{~b}$ & 15.99 & 16.49 \\
\hline Compost & 1.46 & $1.66 \mathrm{c}$ & $6.17 \mathrm{~b}$ & $26.29 \mathrm{~b}$ & $30.39 \mathrm{~b}$ & $4.84 \mathrm{bc}$ & 5.08 & $9.63 \mathrm{~b}$ & 15.77 & 13.42 \\
\hline Compost $+\mathrm{T} 382$ & 1.33 & $1.73 \mathrm{c}$ & $7.98 \mathrm{~b}$ & $19.78 \mathrm{~b}$ & $24.89 \mathrm{~b}$ & $4.56 \mathrm{c}$ & 5.98 & $10.29 \mathrm{~b}$ & 14.83 & 14.32 \\
\hline Compost & - & $0.10 \mathrm{~b}$ & $1.41 \mathrm{~b}$ & $5.55 \mathrm{~b}$ & 4.47 & - & - & $2.63 \mathrm{~b}$ & $6.63 \mathrm{~b}$ & 2.04 \\
\hline Compost $+\mathrm{T} 382$ & - & $0.11 \mathrm{~b}$ & $1.71 \mathrm{~b}$ & $5.00 \mathrm{~b}$ & 2.99 & - & 一 & $2.38 \mathrm{~b}$ & $5.63 \mathrm{~b}$ & 1.87 \\
\hline Telone C35 & - & $0.24 \mathrm{a}$ & $2.93 \mathrm{a}$ & $10.6 \mathrm{a}$ & 4.31 & - & - & $3.80 \mathrm{a}$ & $9.50 \mathrm{a}$ & 1.17 \\
\hline \multirow[t]{2}{*}{ LSD } & - & 0.098 & 0.71 & 2.49 & NS & - & - & 0.95 & 2.18 & NS \\
\hline & \multicolumn{10}{|c|}{ Feeder roots $(1=$ none, $10=$ abundant $)$} \\
\hline Untreated & 7.58 & $8.17 \mathrm{ab}$ & $8.33 \mathrm{ab}$ & $6.00 \mathrm{ab}$ & $7.17 \mathrm{~b}$ & 7.875 & 8.63 & 8.19 & 7.31 & $7.88 \mathrm{~b}$ \\
\hline Compost & 6.17 & $7.58 \mathrm{bc}$ & $7.25 \mathrm{c}$ & $5.17 \mathrm{~b}$ & $6.50 \mathrm{bc}$ & 7.375 & 8.50 & 7.88 & 7.31 & $7.00 \mathrm{c}$ \\
\hline Compost $+\mathrm{T} 382$ & 7.17 & $6.92 \mathrm{c}$ & $7.75 b c$ & $5.00 \mathrm{~b}$ & $6.17 \mathrm{c}$ & 7.0625 & 8.44 & 8.25 & 7.56 & $7.50 \mathrm{bc}$ \\
\hline Telone C35 & 7.83 & $9.00 \mathrm{a}$ & $9.08 \mathrm{a}$ & $7.17 \mathrm{a}$ & $9.33 \mathrm{a}$ & 8.00 & 8.44 & 8.50 & 6.38 & $9.25 \mathrm{a}$ \\
\hline LSD & NS & 1.06 & 0.95 & 1.28 & 0.75 & NS & NS & NS & NS & 0.71 \\
\hline
\end{tabular}

Values shown are means of four replications averaged over transplant treatments ( $\mathrm{n}=12$ in year 1 and $\mathrm{n}=16$ in year 2). Values followed by the same letter within columns are not significantly different $(P \geq 0.05)$ according to Fisher's protected LSD.

${ }^{\mathrm{N}}$ Nonsignificant.

Table 2. Yield of strawberry plants grown in field soil with different treatments.

\begin{tabular}{|c|c|c|c|c|c|c|}
\hline \multirow[b]{2}{*}{ Soil treatment } & \multicolumn{2}{|c|}{$\begin{array}{l}\text { Total yield } \\
\text { (g/plant) }\end{array}$} & \multicolumn{2}{|c|}{$\begin{array}{c}\text { Marketable yield } \\
(\mathrm{g} / \mathrm{plant})\end{array}$} & \multicolumn{2}{|c|}{$\begin{array}{c}\text { Avg fruit } \\
\text { wt (g/berry) }\end{array}$} \\
\hline & Yr 1 & Yr 2 & Yr 1 & Yr 2 & Yr 1 & Yr 2 \\
\hline Untreated & $401.3 \mathrm{~b}$ & $431.3 \mathrm{~b}$ & $320.4 \mathrm{~b}$ & $311.1 \mathrm{~b}$ & $18.46 \mathrm{~b}$ & $12.30 \mathrm{~b}$ \\
\hline Compost & $310.8 \mathrm{c}$ & $409.8 \mathrm{~b}$ & $247.8 \mathrm{c}$ & $282.7 \mathrm{~b}$ & $18.41 \mathrm{~b}$ & $12.26 \mathrm{~b}$ \\
\hline Compost $+\mathrm{T} 382$ & $315.5 \mathrm{c}$ & $377.4 \mathrm{~b}$ & $257.8 \mathrm{c}$ & $257.4 \mathrm{~b}$ & $17.91 \mathrm{~b}$ & $12.02 \mathrm{~b}$ \\
\hline Fumigant TC35 & $652.7 \mathrm{a}$ & $599.3 \mathrm{a}$ & $463.7 \mathrm{a}$ & $393.8 \mathrm{a}$ & $20.62 \mathrm{a}$ & $13.14 \mathrm{a}$ \\
\hline LSD & 60.9 & 74.8 & 52.1 & 57.9 & 1.5 & 0.6 \\
\hline
\end{tabular}

Values followed by the same letter within columns are not significantly different $(P \geq 0.05)$ according to Fisher's protected LSD.

while the compost-based treatments had similar, or sometimes detrimental, effects compared with the untreated control (Table 1). Addition of the biocontrol agent T382 to the compost did not improve growth or productivity compared with compost used alone (Table 1).

Root dry weight more than doubled between December and April in all treatments in Year 2, but root growth was slower in Year 1 (Table 1). Root dry weight decreased between full bloom (April) and peak fruiting (early May) in both years and then increased again until final harvest, more than doubling in some cases. In contrast, crown weight increased steadily throughout the growing season starting from planting and was always greatest in fumigated plots. Production of aboveground plant parts (leaves and fruiting structures) was most pronounced starting in February.
Total and marketable yield and fruit weight were significantly greater in the fumigated soil compared with any other soil treatment (Table 2). Total yield was lower in the compost treatment compared with the untreated control in Year 1, but no differences were observed in Year 2.

Soil chemical analysis indicated that the concentration of $\mathrm{K}, \mathrm{Mg}$, and $\mathrm{Ca}$ was significantly greater in field soil amended with compost than in untreated or fumigated soil, but there were no differences in the concentration of other nutrients $(\mathrm{P}, \mathrm{Na}, \mathrm{Mn}, \mathrm{Zn}$, and $\mathrm{Cu}$ ) or organic matter content (data not shown). Soil populations of parasitic nematodes, including Pratylenchus penetrans (Cobb) Filip \& Schur. Stek (lesion nematode), which causes strawberry black root rot (Wing and Pritts, 1994), were below levels that could cause root damage (NCDA\&CS). For example in the terminal 2004 sampling, one sample (plot) had a $P$. penetrans level of 10 per $500 \mathrm{~cm}^{3}$ of soil, and 31 plots (from a total of 64) had the stunt nematode (Tylenchorhynchus Cobb) with an average count of 181 nematodes per $500 \mathrm{~cm}^{3}$ of soil. These populations were unaffected by soil treatment and were considered below threshold. Incidences for other species, such as Meloidogyne Goeldi (root knot), Helicotylenchus Steiner (spiral), and Paratrichodorus Siddiqi (stubby) nematodes, ranged from 1 to 6 plots with a titer considerably below economic thresholds.

\section{Discussion}

In this study, compost and Trichoderma soil amendments did not offer any practical benefits for strawberry production, while soil fumigation increased plant growth and yield compared with untreated soil. T382 increased transplant growth in one year and suppressed disease the second year but did not offer consistent or long-term effects in the field. This strain has performed well in potted ornamental systems against Pythium and Rhizoctonia species (Chung and Hoitink, 1990; Krause et al., 2001), primary strawberry root pathogens in the southeastern United States (Abad et al., 2002; Ferguson et al., 2003). Our study was the first to evaluate the effects of T382 on plant growth in field conditions and on strawberry production systems. We previously reported 
(Leandro et al., 2006) that, in this study, we successfully established and sustained a population of T382 in field soil throughout the growing season using compost as a delivery system. However, T382 application to field soil did not enhance plant growth or yield. It is possible that the levels of T382 achieved were lower than desirable or that this strain is not well adapted to our field conditions. In other studies (Elad et al., 1981; Olatinwo and Schilder, 2002), T. harzianum biocontrol strains applied to strawberry transplants enhanced growth and yield in production fields. Biocontrol formulations with two bacteria and chitin, applied to strawberry transplants, have offered yield benefits in other production regions (Kokalis-Burelle, 2003). On the basis of our findings, we conclude that additional work is needed to determine if Trichoderma applications would offer benefits in strawberry production systems typical for our region.

Compost applications have improved plant growth and yield of several crops (Bulluck and Ristaino, 2002; Maynard and Hill, 2000; Roe, 1998), but-in our trialscompost had no beneficial, and sometimes detrimental, effects compared with untreated soil. Other compost studies on strawberry are limited and have shown both positive (Grabowski, 2001; Wang and Lin, 2002) and neutral outcomes (Sances and Ingham, 1997). Variability in compost performance is one of the main limitations of its widespread use in agriculture (De Ceuster and Hoitink, 1999; Millner et al., 2004). The level of decomposition, nutrient and salt concentrations (Hoitink and Boehm, 1999; Millner et al., 2004), and soil management history (Sances and Ingham, 1999), largely determine disease suppression and plant growth promotion by composts. In our trials, soluble salt concentration increased, but stayed within acceptable ranges for strawberry production, in compost-amended soil. We also have no evidence for the introduction of pathogens in the compost (Leandro et al., 2005), so the ineffectiveness of compost in our trials cannot be clearly explained. Several applications of organic matter may be needed to build up beneficial organisms, and substantially improve soil characteristics, before compost benefits become apparent (De Ceuster and Hoitink, 1999; Sances and Ingham, 1997).

Fumigation increased dry weight of roots, crowns, leaves, and fruiting structures, as well as yield, compared with all other treatments. Total and marketable yield increased by $25 \%$ to $110 \%$ in fumigated soil compared with untreated soil, confirming previous reports that Telone $\mathrm{C} 35$ is an effective soil fumigant (Martin, 2003). Improvements in plant growth and yield resulting from fumigation are well known (Wilhelm and Paulus, 1980; Yuen et al., 1991) and most often associated with reductions in weed, pathogen, and nematode pressure. Nematode populations in field soil were not sufficient to cause root damage and therefore did not play a role in our results (data not shown). How- ever, we determined, in companion reports, that root rot severity was lower and fungal pathogens were less frequent on roots growing in fumigated plots than in the other treatments (Leandro et al., 2005). In addition, fumigated soil had larger (3- to 60-fold) populations of native Trichoderma species (different from applied strains T382 or T22) than nonfumigated soil (Leandro et al., 2006). Postfumigation colonization by native biocontrol agents has been associated with improved plant growth when disease and weed pressure are low (De los Santos, 2003). In our trials, increased yield in fumigated plots may have resulted from a combination of reduced pathogen pressure or greater native Trichoderma populations.

Successful implementation of compost and biologically based systems to manage disease and improve crop health and productivity are more dependent on strategic management decisions and site-specific adaptation than chemical-based fumigation systems. The popularity of methyl bromide use, in part, relates to the efficacy of the product across many regions of strawberry production that vary in soil type, climate, and management inputs. It is not site-specific but a general tool. Telone C35 has also performed reliably at multiple sites in the Southeastern region and over multiple years (Ferguson et al., 2002; Sydorovych et al., 2006; this study). We have implemented compost-based systems with success at other sites (Grabowski, 2001; Louws et al., 2000) but did not see the same benefits in this study. This study illustrates the site-specific dynamics that growers must manage when using biologically based alternatives to fumigants for strawberry production. No single fumigant is as effective as methyl bromide, and biological alternatives are more site-specific and system-dependent in their results. The task remains to develop a reliable strawberry production system in the southeastern United States that does not rely on chemical fumigation, that maintains adequate plant health and yields, and that can be easily implemented by growers in the region.

\section{Literature Cited}

Abad, Z.G., F.J. Louws, G.E. Fernandez, and L.M. Ferguson. 2002. Predominance and pathogenicity of fungi and stramenopiles associated with black root rot (BRR) of strawberries. Phytopathology 92:S1.

Bulluck, L.R., III and J.B. Ristaino. 2002. Effect of synthetic and organic soil fertility amendments on southern blight, soil microbial communities, and yield of processing tomatoes. Phytopathology 92:181-189.

Chung, Y.R. and A.J. Hoitink. 1990. Interactions between thermophilic fungi and Trichoderma hamatum in suppression of Rhizoctonia damping-off in a bark compost-amended container medium. Phytopathology 80:73-77.

De Ceuster, T.C.C. and H.A.J. Hoitink. 1999. Prospects for composts and biocontrol agents as substitutes for the methyl bromide in biological control of plant diseases. Compost Sci. Util. 7:6-15.
De los Santos, B., C. Barrau, C. Blanco, F. Arroyo, M. Porras, J.J. Medina, and F. Romero. 2003. Relationship between Trichoderma soil populations and strawberry fruit production in previously fumigated soils. HortScience 38:1400-1402.

Elad, Y., I. Chet, and Y. Henis. 1981. Biological control of Rhizoctonia solani in strawberry fields by Trichoderma harzianum. Plant Soil 60:245-254.

EPA. 1999. Protection of stratospheric ozone: incorporation of Montreal Protocol adjustment for a 1999 interim reduction in class I, group IV controlled substances. Fed. Regist. 64:2924029245.

Ferguson, L.M., F.J. Louws, Z.G. Abad, G.E. Fernandez, E.B. Poling, and P.M. Brannen. 2003. Strawberry root colonization by pathogens in transplants and field set plants. Phytopathology 93:S25.

Ferguson, L.M., F.J. Louws, G.E. Fernandez, P.M. Brannen, E.B. Poling, O.B. Sydorovych, C.D. Safley, D.W. Monks, Z. Pesic-Van Esbroeck, D.C. Sanders, and J.P. Smith. 2002. Chemical and biological alternatives to methyl bromide for strawberry in the Southeastern US. Proc. 2002 Ann. Intl. Res. Conf. Methyl Bromide Alternative Emissions Reduction. 21 June 2006. <http://www.mbao.org/2002 proc/ mbrpro02.html>.

Grabowski, M.A. 2001. Biologically and chemically based alternatives to methyl bromide fumigation in strawberry production. North Carolina State University, Raleigh, N.C., MS Thesis.

Harman, G.E. 2000. Myths and dogmas of biocontrol: changes in perceptions derived from research on Trichoderma harzianum T-22. Plant Dis. 84:377-393.

Hoitink, H.A.J. and M.J. Boehm. 1999. Biocontrol within the context of soil microbial communities: a substrate-dependent phenomenon. Ann. Rev. Phytopathol. 37:427-446.

Hoitink, H.A.J., A.G. Stone, and D.Y. Han. 1997. Suppression of plant diseases by composts. HortScience 32:184-187.

Howell, C.R. 2003. Mechanisms employed by Trichoderma species in the biological control of plant diseases: the history and evolution of current concepts. Plant Dis. 87:4-10.

Kokalis-Burelle, N. 2003. Effects of transplant type, plant growth-promoting rhizobacteria, and soil treatment on growth and yield of strawberry in Florida. Plant Soil 256:273-280.

Krause, M.S., L.V. Madden, and H.A.J. Hoitink. 2001. Effect of potting mix microbial carrying capacity on biological control of Rhizoctonia damping-off of radish and Rhizoctonia crown and root rot of poinsettia. Phytopathology 91:1116-1123.

Leandro, L.F.S., L.M. Ferguson, G.E. Fernandez, and F.J. Louws. 2005. Population dynamics of fungi associated with strawberry roots in different soil management systems. Phytopathology 95:S57.

Leandro, L.F.S., T. Guzman, L.M. Ferguson, G.E. Fernandez, and F.J. Louws. 2006. Population dynamics of Trichoderma in fumigated and compost-amended soil and on strawberry roots. Appl. Soil Ecol. 35:237-246.

Louws, F.J., M.A. Grabowski, G.E. Fernandez, and J.B. Vollmer. 2000. Compost as an alternative to methyl bromide in plasticulture strawberry production. Proc. 2000 Ann. Intl. Res. Conf. Methyl Bromide Alternative Emissions Reduction. 21 June 2006. <http://www.mbao.org/ altmet00/33louws.pdf $>$. 
Maas, J.L. 1998. Compendium of strawberry diseases. 2nd ed. APS Press, St. Paul, MN.

Martin, F.N. 2003. Development of alternative strategies for management of soilborne pathogens currently controlled with methyl bromide. Ann. Rev. Phytopathol. 41:325-350.

Maynard, A.A. and D.E. Hill. 2000. Cumulative effect of leaf compost on yield and size distribution in onions. Compost Sci. Util. 8:12-18.

Millner, P.D., C.E. Ringer, and J.L. Maas. 2004. Suppression of strawberry root disease with animal manure composts. Compost Sci. Util. 12:298-307.

NCDA\&CS. North Carolina Department of Agriculture and Consumer Services. 2006. 21 June 2006. <http://www.agr.state.nc.us/agronomi/ nemhome.htm>

Olatinwo, R.O. and A.M.C. Schilder. 2002. Transplant root dips with biocontrol agents reduce strawberry black rot. Phytopathology 92:S61.

Poling, E.B. 2001. Strawberry plug propagation. Berry Agent, Vol. 2, No. 42. 21 June 2006.
$<$ http://intra.ces.ncsu.edu/depts/hort/berrydoc/ june $15 /$ index $>$.

Roe, N.E. 1998. Compost utilization for vegetable and fruit crops. HortScience 33: 934-937.

Safley, C.M., E.B. Poling, M.K. Wohlgenant, O. Sydorovych, and R.F. Williams. 2004. Producing and marketing strawberries for direct market operations. HortTechnology 14:124-135.

Sances, F.V. and E.R. Ingham. 1997. Conventional and organic alternatives to methyl bromide on California strawberries. Compost Sci. Util. 5:23-37.

Sances, F.V. and E.R. Ingham. 1999. Conventional and organic alternatives to methyl bromide on California strawberries. Proc. 1999 Ann. Intl. Res. Conf. Methyl Bromide Alternative Emissions Reduction. 21 June 2006. <http://www. mbao.org/mbrpro99.html $>$. <http://hortweb. cas.psu.edu/extension/vegcrops/vegetable_ gazette/2004/oct2004.htm\#organic $>$.
Sydorovych, O.B., C.D. Safley, L.M. Ferguson, E.B. Poling, G.E. Fernandez, P.M. Brannen, D.M. Monks, and F.J. Louws. 2006. Economic evaluation of the methyl bromide alternatives for the production of strawberries in the Southeastern US. HortTechnology 16:118128.

Wang, S.Y. and S.S. Lin. 2002. Composts as soils supplement enhanced plant growth and fruit quality of strawberry. J. Plant Nutr. 25:22432259.

Wilhelm, S. and A.O. Paulus. 1980. How soil fumigation benefits the California strawberry industry? Plant Dis. 64:264-270.

Wing, K.B. and M.P. Pritts. 1994. Strawberry black root rot: a review. Adv. Strawberry Res. 13:1319.

Yuen, G.Y., M.N. Schroth, A.R. Weinhold, and J.G. Hancock. 1991. Effects of soil fumigation with methyl bromide and chloropicrin on root health and yield of strawberry. Plant Dis. 75:416-420. 